\title{
A Probe Into Li Bai’s Fifty-Nine Pre-Tang Style Poems (XIX)*
}

\author{
ZHANG Pei \\ Beijing Institute of Graphic Communication, Beijing, China
}

\begin{abstract}
There are many problems worth discussing in Li Bai's Fifty-Nine Pre-Tang Style Poems (XIX), which can be named Lotus Flower Peak in Huashan Mountain (西岳莲花山). From ancient times to the present, interpreters have put forward different opinions on the theme, period, and writing place of the poem, but they have not provided reliable evidence. From the perspective of historical geography, this paper elaborates on "Lotus Flower Peak" or “Lotus Flower Mountain” (莲花峰或莲花山) and “Luoyang Chuan” (洛阳川) in the poem, and puts forward a series of viewpoints for the first time. Li Bai chose Huashan Mountain as the starting point of his journey to the mystical landscape because of the special location of Yuntai Peak. Its position is easy to observe from east to west, thus forming an eastward immortal route contrary to the western route of the rebels of An Lushan and Shi Siming (安史叛军). It shows great significance to the division of the poet’s personal life stages that Li Bai started to use the word "Luoyang Chuan". There is a significant difference between this word and the pure word "Luoyang" when it combines the applied allusion of the An-Shi Rebellion. According to the research results, this poem may be written during this period from January in 756 A.D. to October in 757 A.D. The poet did not enter Tongguan in Shaanxi at all, let alone climbing Yuntai Peak in Huashan Mountain. In this poem, the real geographical position runs through the whole process, making the poet's romantic fairy fantasy and the real historical record perfect integration, fully showing the poet's judgment of the current situation and the course of his mind in the An-Shi rebellion.
\end{abstract}

Keywords: Li Bai, the Fifty-Nine Pre-Tang Style Poems (XIX), Lotus Flower Mountain, Luoyang, Luoyang Chuan

\section{Presentation of Problems}

The 19th poem of Li Bai's Fifty-Nine Pre-Tang Style Poems:

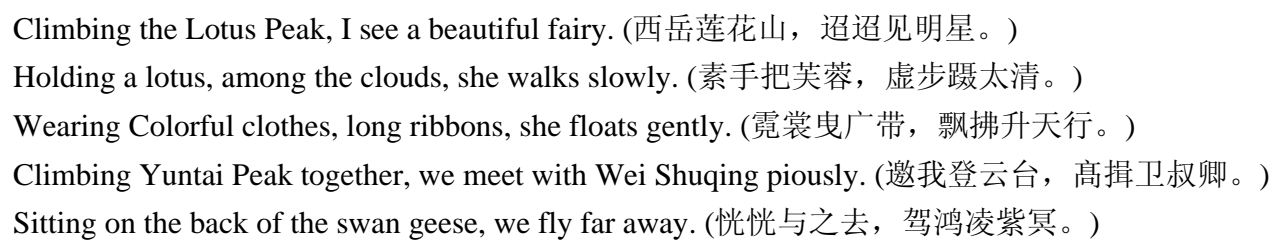

\footnotetext{
* This paper is the periodic research result of the research project: Beijing Social Science Fund Project, "Research on The Yuan Dynasty Version of Li Taibai's Poems With Supplementary Annotations by Classification, Collected by Zunjing Pavilion in Japan" (日本尊经阁藏元版《分类补注李太白诗》研究) (Serial Number 15WYC060). Moreover, it is also the periodic research result of the research project: Planning of Philosophy and Social Sciences in Guizhou Province in 2018-Individually Listed Studies of Chinese Ancient Civilization (贵州省 2018 年度哲学社会科学规划国学单列课题阶段性成果), “Research on the Compilation and Publication of the Anthology of Special Collections of the Works of Scholars of Song Dynasty in Song and Yuan Dynasties” (宋元时期宋人别集的编纂与刊刻研究) (Serial Number 18GZGX25).

ZHANG Pei, L.D., post-doctoral of law, lecturer, graduate student instructor, School of Journalism and Publication, Beijing Institute of Graphic Communication, Beijing, China.
} 
Looking down at Luoyang Chuan, I see the rebels of An-Shi suddenly. (俯视洛阳川, 茫茫走胡兵。)

Bleeding everywhere, all beings are abused by jackals and wolves cruelly. (流血涂野草, 豺狼尽冠纱。) (Yang \& Xiao, 2006, pp. 186, 187)

Yang Qixian (杨齐贤) was an annotator in the Southern Song Dynasty. He said:

When Li Bai was in the Hanlin Academy (翰林院), he had different values from those of the officials around him, so he quickly left and started to lead a foot-loose traveling life. Shortly afterwards, the An-Shi rebellion broke out. It showed that Li Bai was really able to avoid disaster and protect himself. (Yang \& Xiao, 2006, p. 187)

Xiao Shiyun (萧士望) also annotated poems of Li Bai. He lived in the late Song Dynasty and the early Yuan Dynasty. He had his own views on Li Bai’s poem:

Mencius said: “On top of the Mount Tai, the world seems so small” (登泰山而小天下). On these grounds, If we climb Mount Huashan, we will be able to overlook the whole Luoyang Chuan. The history of Tang Dynasty relates that the court rewarded the magistrates as rewards for their meritorious generals between 756 A.D. and 758 A.D. (至德年间). During the An-Shi Rebellion, the court borrowed the Huihe (回纥) troops to recover Chang'an, the western capital, and Luoyang, the eastern capital. That's what Li Bai wrote, "I see the rebels of An-Shi suddenly” and "All beings are abused by jackals and wolves cruelly". And on the base of the above, this poem seems to be a realistic work. Perhaps when the An-Shi rebels invaded Luoyang, Li Bai happened to be at Yuntai Taoist temple in Huashan Mountain. (Yang \& Xiao, 2006, pp. 186, 187)

Wang Qi (王琦), annotator of Qing Dynasty, did not agree with Xiao Shiyun’s view. He believed that the poem was written after the fall of Luoyang. "The rebels” should refer to military forces of An Lushan. "The jackals and wolves” (㥪狼) should refer to the rebellious ministers and villains that reused by An Lushan. By this token, the historical facts of Xiao Shiyun's textual research were not clear (Wang, 1977, p. 114).

Modern and contemporary scholars have many doubts about ancient annotations. As one of them, Zhan Ying (詹锳) believed that this poem was written before the fall of Chang'an, because there was no mention of Chang'an at all (Zhan, 2016, p. 124). Qu Tuiyuan (篗蜕园) and Zhu Jincheng (朱金城) objected to Xiao Shiyun's viewpoint. They thought that the sentence in Li Bai's poem, "Sitting on the back of the swan geese, we fly far away”, could not directly prove that he was in Yuntai Taoist temple (Qu \& Zhu, 1980, p. 131). Scholar An Qi (安旗) supported Wang Qi’s view as Xiao Shiyun's annotations are not accurate enough. She believed that after the outbreak of the An-Shi Rebellion, the Central Plains fell into enemy and Li Bai had to take refuge in Southeast China. But he was always concerned about the Central Plains, so he wrote this poem to express his sadness (An, 2015, p. 1211).

When interpreting Li Bai's poem, the annotators above pay more attention to the historical period and geographical position, usually focusing on the former, while paying less attention to the latter and failing to explain it clearly. Therefore, this paper tries to discuss the exact geographical position in the poem which is essential to interpret Li Bai's poems.

Through carefully anglicizing this poem, the author found that there are two key place names in the poem: One is the Lotus Mountain (Huashan Mountain) and the other is the Luoyang Chuan.

\section{Interpretation of "Lotus Mountain” and "Yuntai"}

Lotus Mountain, in Huayin County of Shaanxi Province (陕西华阴), Erya (《尔雅》) records “Huashan Mountain is the western mountain”. Fairy Tales (《集仙传》) relates that Yunü named Star (明星玉女) lives in 
Huashan Mountain who is in fond of drinking elevated her body and flew away one day. According to the above records, the fairy mentioned by Li Bai in his poem "I see a beautiful fairy" happens to be the Yunü named Star lives in Huashan Mountain. Compared with Fairy Tales, Ancient Stories of Immortals (《集仙录》) records the realistic landscape of Yunü's residence more completely:

There is a big stone turtle on the top of the mountain, which covers several $\mathrm{mu}^{1}$, three hectares high and has a ladder on the side. Climb on it, and you will see all around. There are five stone mortars in front of the Yunü Temple, which can be called the Yunü-Shampoo basins. The water in these basins is green and clear. When it rains, the water will not overflow; when it is dry, the water will not decrease. Entering the Temple, you can see a jade horse. (Yang \& Xiao, 2006, p. 186)

As far as the scenes set in the fairy-illusion poem are concerned, this is Li Bai's first stop in Huashan. Because there is such an exact place related to immortals, he could describe to his heart how he met the immortals. In terms of linguistic structure, the subject of the first rhyme of this poem is Li Bai, and the subject of the second rhyme is Yunü. What Li Bai said "Holding a lotus, among the clouds, she walks slowly" means that the poet rose in the daytime under the leadership of the Yunü named Star. Meanwhile, what does the “lotus” mean? Wang Yi (王逸), a literature of the Eastern Han Dynasty, annotated Chu Ci (Songs of the South, 《楚辞》): “Lotus means flower”. Biography of Huashan (《华山记》) records that a kind of lotus on the top of Huashan Mountain named Thousand-Petal Lotus which can make people become immortal while eating it. Therefore, Huashan Mountain can also be called Lotus Mountain (Yang \& Xiao, 2006, pp. 186, 187). These place names have given Li Bai rich associations. Therefore, the content of the poem is to connect between fiction and reality naturally, so that the image can be colored with romance on the basis of reality, and create an atmosphere for "rising in the daytime".

After that, Li Bai led by the fairy came to Yuntai and met the fairy Wei Shuqing. So Li Bai wrote "Climbing Yuntai Peak together, we meet with Wei Shuqing piously". Xiao Shiyun annotates "Yuntai" in this way:

Records of Huayue (《华岳记》), one of the chapters of the book Biographies of Kaiyuan Period in Tang Dynasty (《唐 开元记》), records that mountains rise above the central part of Yuntai. (Yang \& Xiao, 2006, p. 187)

Wang Qi quoted Records of Famous Mountains (《名山记》), written by Shen Meng (慎蒙) of Ming Dynasty, when annotating Li Bai's poems: "Yuntai Peak is located in the northeast of Huashan Mountain. There are two peaks both very steep, which connect the upper cloud layer and the lower ground vein. They stand alone, just like human forehead” (Wang, 1977, p. 114).

Scholar An Qi's notes:

Yuntai, the Yuntai Peak of Huashan Mountain, which in the northeast of Huashan Mountain. Among the five peaks in Huashan, Yuntai is the lowest. Standing on it, you can overlook the Yellow River, Weihe River and other mountains. They all lists in the field of vision, like thin lines, like gravel. Of course, if you stand at Yuntai Peak and look up at the other three peaks, you will feel yourself standing in the middle of the sky. In addition, the location of the Yellow River is about twenty miles northeast of Yuntai Peak. (An, 2015, p. 1210)

To sum up, Xiao Shiyun quoted the record of “Yuntai” from Record of Huayue (《华岳记》), and thought that it was not different from "Yuntai Peak". It was located in the mountain valley, which not the Taoist temple

\footnotetext{
${ }^{1} \mathrm{Mu}$, a unit of area (= 0.0667 hectares).
} 
built by Emperor Wu of the Later Zhou Dynasty for Taoist priest Jiao Daoguang (焦道广) and not the place ancestor Chen Tuan (陈抟) lived in seclusion later. It can be said that Xiao Shiyun's understanding of this poem is in line with Li Bai's visit to Huashan when he wrote poems. Purely as far as Yuntai Peak is concerned, its terrain is quite special. In Records of Famous Mountains, the mountain is described as “Ling tai” (灵台), and this word is often used to refer to the head or heart of a person in Taoist discourse system. In the First Part of Shangqing Huangting Waijing Jing (《上清黄庭外景经・上部经》), one of the classical works of Taoist, Lingtai is considered to be able to go up to the sky and down to the field. Wu Cheng-tse (务成子), a representative of Taoism in history, believed that the head is like a high platform and the intestines are like vast fields. Li Yiyuan (李一元) of Ming Dynasty explained that if the heart is regarded as the monarch of the human body, then the place where he lives can be called Lingtai. The spirit of Lingtai can reach the sky, and its position is in the middle of the field (Liang, 2015, p. 413). They mean that Yuntai Peak is situated in a relatively independent position surrounded by three peaks. It is as high as a human head and as vital as a human heart, which is especially suitable for overlooking the earth from mid-air. However, the overlooking perspective is most suitable for looking east and west; while looking south, you can see three other peaks of Huashan Mountain. They are South peak named Dropping Goose Peak (落雁峰), West Peak named Lotus Peak (莲花峰), East Peak named Chaoyang Peak (朝阳峰), respectively. Li Bai wrote in another poem, Song of Yuntai Peak一Farewell Song to Dan Qiu-tse (《西岳云台歌送丹丘子》), “There are three dangerous peaks, steep and steep, which seem to be broken by erection; There are cliffs and valleys, deep and deep, which seem to be split by the river god” (三峰却立如欲摧, 翠崖丹谷高掌开) (Wang, 1977, p. 381). These two sentences vividly describe the scenes that people can see when they are in Yuntai Peak, which can be used to prove the previous annotators' understanding of Yuntai Peak.

Therefore, in this poem, Li Bai's choice of route for his fairy illusion is to travel eastward with the immortal Wei Shuqing. Only in this way can the two sentences, "Sitting on the back of the swan geese, we fly far away" and "Looking down at Luoyang chuan, I see the rebels of An-shi suddenly" be connected smoothly and the fiction is expressed very truthfully. Perhaps because people can easily be misled by its fictional nature when they understand the poems about immortals, they think that all this type of poetry is full of illusions, but that may not be the case entirely. Like Li Bai, he often climbed Mount Huashan and became very familiar with the terrain. This route, literally guided by immortals, was constructed by the poet according to the real geographical environment. Thus the author has two points that need further elaboration:

Firstly, Li Bai, as a Taoist who received Taoist diagrams and scriptures, is accustomed to choosing Taoist holy places as the geographical environment for imagination when he writes immortal poems. For example, the poem Mount Skyland Ascended in a Dream—A Song of Farewell (《梦游天姥吟留别》) was written by Li Bai before his departure from Eastern Shandong to the Southern. It means that the poet was still in Eastern Shandong when he wrote about Southern things in his poems. National Chorography Describes Shaoxing Imperial Court (《一统志・绍兴府》):

The Mount Skyland, in the Xinchang county (新昌) east five miles, three thousand and five hundred zhangs high, sixty miles circumference. To the east, it connects the Huading Peak of Tiantai Mountain. Universal Geography of the Taiping Era (976 A.D.-983 A.D.) (《太平寰宇记》) records that those who climb this mountain can hear the song of the Heavenly Queen Mother (西王母). That’s why the Mount Skyland is known as the sixteenth blessed place of Taoism in Taoist Scriptures. (An, 2015, p. 721) 
Secondly, the style of Li Bai's poems about immortals is often in a certain condition between "immortals" and "dreams". The former is the content of dreams, while the latter is the cause of immortals. As a result, he will escape from dreams and return to reality, so that he can instantly express his perception of the world, which is between dream and awakening, reality and illusion. Li Bai is accustomed to using this method of writing poems, which is particularly prominent in Pre-Tang poems that is not particular about antithesis and the four tones of classical Chinese phonetics, but about sentiment and momentum. At first, it was not confined to the use of poems of fairyland excursion. After a long time of use, it was used thoroughly. From 730 A.D. to 759 A.D., Li Bai wrote many poems in this way. In order, they are Imitation of Ancient Poems (《拟古》) (II) (VII), Invigoration (《感兴》) (II), Fifty-Nine Pre-Tang Style Poems (《古风五十九首》) (VII) (LVI), Simulation (《效古》) (I), Fifty-Nine Pre-Tang Style Poems (V)(XX)(LV)(XVIII) (IV) (XIX) (LVIII). From the narrative point of view, these poems are basically in accordance with such a model "Event 1-A sudden turning point—Event 2-Emotions expressed directly—Final attitudes" to promote the content of poems, so that the evolution of the poems has ups and downs; the emotion and the reason can mirror each other.

It can be said that the use of real geographical names in such poems can naturally communicate the turning points and events in the writing mode, which makes the romantic imagination and the real reality naturally merge, and will not fall into a simple corresponding relationship.

Then, if the elucidator regards this poem as a documentary work with political allegorical significance, he will inevitably speculate on the basis of place names like Xiao Shiyun, and think that when the An lushan rebels invaded Luoyang, Li Bai happened to be in the Yuntai Taoism in Huashan. Therefore, when we interpret the poem, it is extremely necessary to make a careful analysis of the second place in the poem, "Luoyang Chuan".

\section{Interpretation of "Luoyang Chuan"}

The last two rhymes of the poem:

Looking down at Luoyang Chuan, I see the rebels of An-Shi suddenly.

Bleeding everywhere, all beings are abused by jackals and wolves cruelly. (Yang \& Xiao, 2006, pp. 186, 187)

Since the beginning of Yang Qixian and Xiao Shiyun, commentators have seldom explained the word "Luoyang", which is generally accepted as "Luoyang City", but neglected to clarify the relationship between the name and the actual reference. This attitude towards the key words has caused many doubts and uncertainties in the interpretation of the poem. Here, the author will sort out the relationship between "Luoyang” and "Luoyang Chuan” from the perspective of historical geography.

\section{Interpretation of "Luoyang”}

First of all, the author will make a textual research on "Luoyang". Luoyang, located in the west of Henan Province and the south bank of the Yellow River, is named for its location on the bank of the ancient Luohe River. A New Account of the Two Capitals (《两京新记》) written by Wei Shu (韦述) in Tang Dynasty described Luoyang as follows:

The two cities were founded in the Sui Dynasty and lasted for about a hundred years until the Kaiyuan Era (713 A.D.-741 A.D.) of the Tang Dynasty. Xijing (西京) started from Kaihuang and Dongdu (东都) from Daye. The western capital Chang'an was founded in Kaihuang period, while the eastern capital Luoyang was founded in Daye Era (605 A.D.-618 A.D.). (Wei \& Du, 2006, p. 2) 
The Eastern capital is commonly known as Luoyang City. In the first year of Daye in Sui Dynasty (605 A.D.), it moved from its former capital to its present position, which was originally the royal city of Zhou Dynasty. From the Emperor Ji Gai (姬包) of the Eastern Zhou Dynasty to the later Han Dynasty, they all lived in their old capital. In the fourth year of Renshou (604 A.D.), Yang Jian (杨坚), Emperor Wen of Sui Dynasty, began to build a new city on the basis of their old capital. Originally known as "Dongjing” (the Eastern capital), it was told to the emperor that an emperor had two capitals, which was unprecedented. Therefore, “Dongjing” (东京) was renamed “Dongdu”. Later, Dongdu was occupied by Wang Shichong (王世充), a general in the late Sui Dynasty, who renamed Dongdu the governor’s Office of Luozhou (洛州总管府). Shortly afterwards, it was set up by Wang Shichong as temporary government of Shaandong Dao (陕东道), the wartime administrative division that was set up in the early Tang Dynasty, was responsible for the management of Luoyang. In the ninth year of Wude (626 A.D.), it was renamed the capital of Luozhou (洛州都督府). In the sixth year of Zhenguan (632 A.D.), the government renamed the old Dongdu Palace as “Luoyang Palace” (洛阳宫). Later, in the first year of Mingqing (656 A.D.), it changed its name back to Dongdu again. Moreover, Empress Wu Zetian called it Shendu (神都). In the first year of Shenlong (705 A.D.), it was changed to Henan prefecture (河南府) as before. The Luohe River (洛河) runs through the city like the Milky Way in the sky. The north side of the city depends on the foothills, and people can see Longmen (龙门) from the south. The Luohe River runs through the city like the Milky Way in the sky. The north side of the city depends on the foothills, and people can see Longmen from the south. It has superior terrain, lush vegetation, and is superior to other cities. (Wei \& Du, 2006, p. 72)

Miscellanies of Daye Era (605 A.D.-618 A.D.) of Sui Dynasty (《大业杂记》), written by Du Bao in Tang Dynasty:

In the first year of Daye of Sui Dynasty (605 A.D.), the emperor ordered the relevant departments to build the eastern capital to the east of the old imperial city of Luoyang. At that time, a scholar named Zhang Qiu Taiyi (章仇太翼) wrote a memorial to Emperor Yang of Sui (隋炀帝), “Your majesty, your destiny is in conflict with Yongzhou (one of nine prefecture in ancient China), so you can’t live in Yongzhou for a long time. During the Kaihuang Era (581 A.D.-600 A.D.), there was a nursery rhyme means imperial career can be achieved by repairing Luoyang. You were once crowned Prince of Jin (晋王), which just fulfilled the nursery rhyme”. While reading the composition, Emperor Yang of Sui was very moved, and immediately had the intention of moving the capital. Then, he went to Luoyang and changed "Luozhou” to "Yu” (豫). There are more than 800 miles from Yuzhou to the capital. The court set up 14 stops, each with palaces and each palace with a main hall. The court also used 500,000 people to open “Tongji Canal” (通济渠), from the Yellow River, through Xingze (䓠泽), and then into the Huaihe River (淮河), about thousands of miles. At the same time, The court used more than 100,000 people in Huainan prefectures and counties to dig Hangou (邗沟). (Wei \& Du, 2006, pp. 107,108)

The 156 volume of Imperial Readings of the Taiping Era (《太平广记》), a well-known book of the Song Dynasty, compiled by scholars such as Li Fang (李昉), Li Mu (李穆), and Xu Xuan (徐铉) of the Northern Song Dynasty, records:

One day, Emperor Yang of Sui climbed the Beimang Mountains (北䢵山) and looked at Yique (伊阙). He turned to the people around him and said, “Is this the Longmen (龙门)? Why didn’t the former emperors build their capital here?” Puye (the governor of Shangshu Province) Su Wei answered, "Of course the former emperors knew it. But such a good place is best for your majesty". The emperor was very happy to hear that. Emperor Taizong of Tang began to live in Luoyang Palace, which still remained the same as it used to be, and nothing changed. Finally, between Zhenguan Era and Yonghui Era, the Luoyang Palace was desolate. (Li, 1960, p. 757)

Later, after Luoyang was designated as the capital city, it was gradually repaired. In Longshuo Era, Emperor Gaozong of Tang asked Sinong Shaoqing (minister of revenue) Wei Ji to repair Luoyang Palace. He told Wei Ji: “Chang'an and Luoyang are both my homes, which I have to live in on an irregular basis. In view of this, you should think carefully about how to repair the Luoyang Palace.” Therefore, some departments built new palaces such as Shangyang Palace. Later, Wu Zetian decided to stay Luoyang. Finally, the palace had a scale. (Li, 1960, p. 759) 
A New Account of the Two Capitals, written by Wei Shu in tang dynasty, is the first account of the two capitals Chang'an and Luoyang. From the general introduction of the book, we can see the understanding of the establishment and change of the two capitals in the Tang Dynasty. First of all, strictly in the capital sense of the two capitals was founded in the Sui Dynasty; in terms of its name, "Luoyang” experienced some adjustments. The reason why Luoyang was renamed "Dongdu" from the original "Dongjing" was because "one emperor had two capitals" did not conform to the ancient system. Therefore, its name was changed to highlight its “companion” meaning, thus creating a difference in status with Chang'an. Later, Wang Shichong became the regent, changed Luoyang's name many times, including "the governor's Office of Luozhou”, "the temporary government of Shaandong Dao", emphasizing the significance of its "resident" government organ from the management level. In the Tang Dynasty, there were a lot of names in turn, "the capital of Luozhou", "Dongdu”, "Shendu", which were related to the adjustment of administrative division and political area in the Tang Dynasty.

Secondly, Emperor Yang of Sui opened the route and possibility of moving the capital eastward since he built the eastern capital, made that statement "The Luohe River runs through the city like the Milky Way in the sky” a reality. These two books, Miscellanies of Daye Era (605 A.D.-618 A.D.) of Sui Dynasty and Imperial Readings of the Taiping Era, record the reasons why Emperor Yang liked Luoyang. The former is close to divination, which combined with mystical Confucians' belief, believed that the fate of the emperor was not compatible with Yongzhou. The latter is the nursery rhyme of the early Sui Dynasty was exactly the same as the one he used to be the ruler of Jin. What is interesting is that the latter seemingly uses literary language to say the coincidence of geography and Destin. However, in essence, it points out that Luoyang's excellent terrain is the original intention of the capital. While building the capital, the Emperor Yang set stops to the west to lead to Chang'an, excavated Tongji Canal to the south to open up water transport, and effectively draw through the waterway from west to east, which was good for the economic center of gravity moving from north to south.

For instance, Receiving Respects at the Qianyang Palace on the Day of the Winter Solstice (《冬至乾阳殿 受朝》), written by the Emperor Yang of Sui:

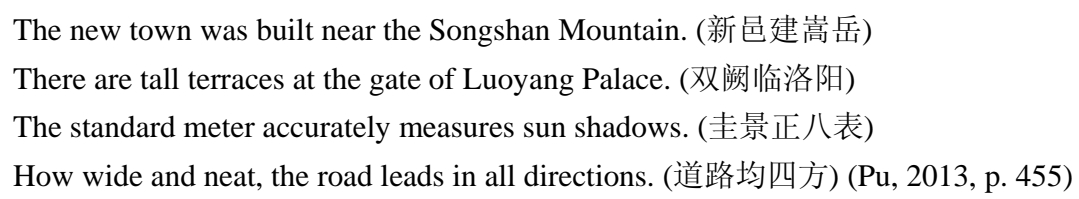

The emperor's joy is expressed in this poem, which describes Luoyang's geographical location and traffic conditions after its construction.

Compared the two reasons mentioned above, there is no conflict. Because of avoidance, there is a desire to move the capital; and because of good location, there is a suitable place to move.

Thirdly, no matter the change of appellation, the original intention of building the capital or the evolution of them, the relationship between Luoyang and Chang'an is very close, reflecting each other. In other words, neither Luoyang nor Chang' an can be completely “independent” in political sense. The Tang Dynasty replaced the Sui Dynasty and took Chang'an as its capital. The Emperor Taizong of Tang Dynasty made his way back and forth between the two capitals. In essence, there was the act of "one emperor had two capitals", which was not a pure implementation of the previous system. Because it was not convenient to travel between the two 
capitals, Emperor Gaozong of Tang asked Wei Ji (韦机) to repair the Luoyang Palace. Wu Zetian ascended the throne. In order to manifest the change of dynasties, she directly appointed Luoyang as the capital, made Chang'an the secondary capital, thus shifted the national power to the east. Later, Emperor Zhongzong of Tang returned to Chang'an, but he was unable to settle down until Emperor Xuanzong of Tang experienced a transitional period, during which the Emperor moved to Luoyang five times.

The alternation of the two places is caused by the complementary demands of geography. Chang'an is located in the west and Luoyang in the east to make up for it, so that the regime has the stability of holding. However, Wu Zetian settled Luoyang the capital to move a large number of powerful families and nobles, and the outbreak of the An-shi Rebellion weakened the power of the Central Shaanxi Plain. Both of them made the trend of moving southeast gradually, which had been formed since the founding of Emperor Yang of Sui Dynasty. In the late Tang Dynasty, Emperor Zhaozong of Tang was moved to Luoyang by Zhu Wen. Since then, “the rotation of capital on the east-west axis took place between Luoyang and Kaifeng (开封)" (Zhou, 2013, p. 253).

Overall, the nature of "Luoyang" is more complex. Its name changes with its status as an accompanying capital. The proportion of man-made development, renovation, construction, and forging is larger than that of Chang'an. It occupies an important position on the axis of the capital of the Yellow River Basin, and becomes the connecting point of the transfer of political power and economy to the southeast. Because of this, there is the momentum of the first-class wealthy and romantic land, and the prestige gradually accumulates in this migration.

\section{Interpretation of "Luoyang Chuan"}

About Luoyang Chuan, there are only three records classified as geographical classics in The Si Ku Quan Shu (or Complete Library in the Four Branches of Literature 《四库全书》). The National Chorography of the Ming Dynasty (《明一统志》) Vol. 37 records: Luoyang Chuan (洛阳川), 25 miles west of Wei City (卫城). The National Chorography of the Qing Dynasty (《大清一统志》) Vol. 37 records: Luoyang Chuan (洛阳川), 25 miles west of Zhongwei County (中卫县), which is commonly mistaken as “Lüechang Lake” (略场湖) in the county annals. The Chorography of Gansu (《甘肃通志》) records: Luoyang Chuan, 25 miles west of Zhongwei County (Work Councils of Si Ku Quan Shu, 2005, p. 431). Zhongwei County mentioned above, set up in 590 A.D., and is the first county-level administrative establishment in Lingwu County (灵武郡), which is 180 miles outside the Yellow River in Lingzhou (west of the Yellow River, north of the Weining Yellow River). Maybe since the Ming Dynasty, "Luoyang Chuan" as an accurate geographical term, refers specifically to the rivers in Ningxia Wei and Zhongwei County of Ningxia Prefecture.

Another poem can be used as a supporting certificate, Passing Mengjin From Henan Province to Beijing (《由豫省回銮渡孟津》), written by the Emperor Kangxi (康熙皇帝):

Seeing Songshan Mountain in the distance, it soars into the clouds, (遥望嵩峰欲逼天)

The Taihang Mountains stretch over the Luoyang Chuan. (太行绵亘洛阳川)

There is no beacon-fire beside “Jinming Pool”; (金明池畔无烽火)

There is fairly smoked scenery before “Zuibai Hall”. (醉白堂前起玉烟)

How vast the central-plains are! How leisurely the people are! (千里中州古击壤)

The Yellow River and the Luohe River rush past by, (两河分界旧原田)

Sitting on the boat quietly, I felt the primitive folk custom. (扁舟稳渡观民俗)

How I wish this place will have good weather for crops every year! (休养心殷冀有年) (College of Liberal Arts of Inner Mongolia University, 2005, p. 307) 
Many geographical names in poetry, including Henan Province, Mengjin (in the north of Luoyang), Jinming Pool (in the northwest of Xizheng Gate in Kaifeng, Northern Song Dynasty), Zuibai Hall (in Anyang, Henan), the central-plains (Henan), clearly indicate that the "Luoyang Chuan" where Kangxi Emperor is located refers to the plain area near the middle of the Yellow River in Luoyang, not the river in Ningxia. However, why did the Emperor Kangxi use word "Luoyang Chuan" that has a non-specific nature when this geographical name already has its specific reference in the Qing Dynasty?

In essence, except for the Emperor Kangxi, only Su Ting and Li Bai who used "Luoyang Chuan” in poetry, the former is the initiator of the word "Luoyang chuan". He wrote the poem Ascending the Taihang Mountains and Expressing Emotion一Upon the Emperor's Order (《奉和圣制登太行山中言志应制》) in January of the 11th year of Kaiyuan. The whole poem is a Pailü poem (排律, or the Pent-syllabic Regulated Verse, long lüshi, usu., each line containing five characters), which has eight rhymes; the six couplets in the middle of poetry are extremely neat. Writing upon the emperor's order, the poet was extremely cautious in the words and sentences. The third rhyme of the poem is, “Looking down at the Henei City, look at luoyang Chuan eye-levelly” (俯观河 内邑, 平指洛阳川) (Editorial Department of Zhonghua Book Company, 1999, p. 808). This group of couplet seems to use an inter-textual rhetoric device. In fact, words in the corresponding positions of the two sentences are actually signified. Otherwise, there will be a taboo for writing poetry called “clasp hands” (合掌, in a set of couplet, words in corresponding positions have similar or identical meanings). What can be speculated is that the specific reference of these two words, "the Henei City" and "the Luoyang Chuan", is significantly different.

It is noteworthy that after the founding of the Tang Dynasty, the principle of regional division based on the trend of mountains and rivers became a formal standard. Although this principle has been implemented long ago, it was not until the Tang Dynasty that it became official ${ }^{2}$. The geography section of The New History of the Tang Dynasty (《新唐书・地理志》) records:

At the beginning of the world, many states and counties were set up. From the first year of Emperor Taizong, he merged the provinces, implement the new principle of administrative division, the domain was finally divided into ten Daos (or ten monitoring areas). (Ouyang \& Song, 1975, p. 959)

In the early Tang Dynasty, these 10 Daos showed the characteristics of "long horizontal and short vertical", mainly because China's overall terrain is high in the west and low in the east, tilting toward the sea, and mountains and rivers are mostly east-west trend. Therefore, according to the new official standards, each Dao looked narrow and long (Tan, 1996, pp. 32, 33). Hedong Dao was sandwiched between Taihang Mountains and Yellow River; Henan Dao was from Shandong Peninsula to the mountainous region of Western Henan (Zhou, 2013, p. 171), and Henei City was bounded by Taihang Mountains which was on the north-south trend, and between Hedong Dao and Henan Dao. After climbing the Taihang Mountains, Su Ting naturally overlooked the narrow Henei Country near him, and looked east and south at the whole Henan Dao. Although his vision cannot be exhausted, according to the direction of Taihang Mountains, his flat-sighted object "Luoyang Chuan" was naturally the whole "Henan Dao", the scope was much broader than "Henei City".

\footnotetext{
2 The delimitation of administrative regions in China follows two basic principles. First, there are interlaces between regions; second, it follows the trend of mountains and rivers. The latter is the more natural and direct one in demarcating boundaries. Chapters on Kingship of the Book of Rite (《礼记-王制》) records, “Different regions have different systems, and different people have their own customs and habits” (Wang, W. J., Interpretation of the Book of Rites. Beijing: Zhong Hua Book Company, 2016). It can be seen that the ancestors already knew how to divide administrative areas according to their geographical location and folklore.
} 
Xuanzong's tour is a major event, so there were many ministers who dedicated to writing poems, besides Su Ting, there were also Miao Jinqing (苗晋卿), Zhang Jiazhen (张嘉贞), and others. Miao Jinqing wrote, "Look ahead and see the city buildings far away, Look down at the Henei City, how smooth it is (关楼前望远, 河邑下观平)” (Editorial Department of Zhonghua Book Company, 1999, p. 2872). Zhang Jiazhen wrote:

Gong County lies to the south, (山南平对巩)

Yanshan Mountain borders to the north. (山北远通燕)

$\cdots$

The mountain road is tortuous, but we are like stepping on the flat ground; (九圻行若砥)

the valley is deep, but our driving is like walking through the flat plain. (万谷辗如川) (Editorial Department of Zhonghua Book Company, 1999, p. 1138)

Compared with the above two poets, in the state of looking down or keep eye-level, Su Ting used the phrase "Luoyang Chuan" to blend the imagination beyond the horizon in realism, which was more magnificent in the overall situation.

Then, looking back at the poem of Eperor Kangxi, it can be found that the sentence "The Taihang Mountains stretch over the Luoyang Chuan” (太行绵亘洛阳川) is based on Su Ting’s, which shows both precise and exquisite characteristics. Emperor Kangxi read Su Ting’s poems from ancient books. So, as a contemporary of Su Ting, did Li Bai definitely read his works? In the poem Paying a Formal Visit to Governor Pei of An Zhou (《上安州裴长史书》), he remembered:

Former Minister of Rites Su Ting (礼部尚书) went to Yi Zhou (益州) as a governor. I went to see him. He treated me with courtesy, and told his colleagues, "This young man is a genius, extremely talented. He writes with great inspiration. Although the style has not yet been fully formed, there is no limit to the future. In time, we should be able to compete him with Sima Xiangru (司马相如)”. At that time, few people did not know what he said of me. (Wang, 1977, p. 1247)

This passage clearly shows that when Li Bai was 20 years old, he had met Su Ting, who had been governor of Yi Zhou since 720 A.D. and was praised by Su Ting. At that time, Su Ting was well-known and influential. Therefore, although Li Bai had not been out of Shu Area (蜀地), he still knew about the world-famous literary giant Su Ting. In addition, as a visitor, it is reasonable to learn the works of the senior through various ways. Li Bai is also a very good learner, he said, "Since the Yellow Emperor (黄帝), he probably knows almost everything, and insist on reading and writing at ordinary times” (Wang, 1977, p. 1243).

In addition, Su Ting (the Duke of Yanguo) was as famous as Zhang Yue (the Duke of Xuguo), the famous Minister of the Kaiyuan era, and was also called “Yan Xu, the Great Authors” (燕许大手笔). Therefore, shortly after his death, Han Xiu, Shangshu of the Ministry of Inspection and Proofreading, compiled a collection of 40 volumes for him, which was stored in the Palace Collection of Books. The moral is that, before the compilation of the anthology, Su Ting's poems and essays had a relatively stable text and a solid basis for dissemination (Chen, 1994, pp. 16, 19). Therefore, whether Li Bai has seen the collection of Su Ting or not, he has sufficient access to Su Ting's works after he left Shu Area, especially this kind of non-personal lyric poems with clear social purpose. From the above, it can be concluded that Li Bai used the phrase "Luoyang Chuan" in his poems, which was originally written by Su Chin.

\section{Integrated Interpretation of "Looking Down at Luoyang Chuan, I See the Rebels of An-Shi Suddenly. Bleeding Everywhere, All Beings Are Abused by Jackals and Wolves Cruelly.”}

In Li Bai's poems, "Luoyang Chuan" is used twice, which is based on the language allusions of his 
predecessors, and has incorporated new events and meanings, namely “An-Shi Rebellion”. This special way of use is evident in the alignment of Li Bai's poems in the early and late stages. "Luoyang" has been used 15 times in his poems, and its different "cultural information" and "regional size" and "creative intention" is combined to construct different "image groups" or "meaning groups" in his poems, which is highly consistent with his mental journey.

Spring in the 12th year of Kaiyuan Era (732 A.D.), Li Bai traveled in Luoyang, wrote a series of poems during this period. Paths in Luoyang (《洛阳陌》):

Whose jade-like handsome boy is this? (白玉谁家郎)

Drive across the Tianjin Bridge. (回车渡天津)

He is admiring the beauty of flowers on the east path, (看花东陌上)

Other people of Luoyang quickly gather and admire the beauty of of him. (惊动洛阳人) (Wang, 1977, p. 317)

The writing style of this poem is not much different from the Yuefu poem "Roads in Luoyang". Both are about the prosperity and leisure of Luoyang City in the spring. The details of this poem is "the Tianjin Bridge" (天津桥).

In the same year, he wrote Your Horse Is Yellow (《君马黄》), which imitated the ancient Yuefu poem, blaming the unpredictable hearts and unsustainable friendship. In the first three rhymes, he wrote:

Your horse is yellow, my horse is white. (君马黄, 我马白)

No matter what color of horse we ride, our minds are always alike. (马色虽不同, 人心本无隔)

On the path of Luoyang, We traveled pleasurably in pair. (共作游冶盘, 双行洛阳陌) (Wang, 1977, p. 337)

Li Bai expressed his attitude towards friendship in the first sentence of his poem, and then wrote that riding together was very intimate, coupled with riding in Luoyang, which added a bit of richness and ease.

Later, Li Bai wrote another poem, Hearing a Bamboo Flute on a Spring Night in Luoyang (《春夜洛城闻 笛》):

From whose house comes the voice of flute of jade unseen? (谁家玉笛暗飞声)

It fills the town of Luoyang, spread by wind of spring. (散入东风满洛城)

Tonight I hear the farewell song of Willows Green. (此夜曲中闻《折柳》)

To whom the tune will not nostalgic feeling bring? (何人不起故园情) (Xu, 2014, pp. 64, 65)

The flute music Willows Green (《折柳》) melodiously reverberates on the spring night. Interpretation of the Tang Poetry (《唐诗歌解》), written by Tang Ruxun (唐汝询) in the Ming Dynasty, comments “the flute sounds are so distant as to be described by the sound floating in Luoyang City” (An, 2015, p. 231). It can really arouse people's homesickness.

In this period when everything went smoothly and the mood was good, the "Luoyang" and "Luoyang City” in Li Bai's works only refer to a city without any additional significance. It is natural in nature; the prosperity of Tianjin Bridge, the spring of Luoyang paths, and the evening of Luoyang City are so peaceful and stable, wealthy and romantic.

In the first year of Tianbao Era (742 A.D.), Li Bai lived in Lu (another name for Shandong Province), wrote To My Friend Zhang Shuming Who Wrote Poems for Me in Nanling at Night (《酬张卿夜宿南陵见赠》). It begins with the follow lines: 
I left the woods once. (我昔辞林丘)

The meeting of monarch and minister is like Long followed by clouds. (云龙忽相见)

However, like a guest star, it offended the Supreme Purple Star. (客星动太微)

I left the palace of Luoyang very soon. (朝去洛阳殿) (An, 2015, p. 398)

An Qi notes, “When Zhang Shuming (张叔明) visited Li Bai at his farmhouse in Nanling, Li Bai was at his home in Xiaqiu (瑕丘), East Lu (东鲁)”, “They got acquainted with each other in Chang'an before” (An, 2015, p. 399). In this line, "I left the palace of Luoyang very soon”, Li Bai described his trip to Chang'an with Yan Ziling's allusion, and implicitly told his friend that his trip was fruitless.

In the sixth year of Tianbao Era (747 A.D.), Li Bai was expelled from the court and wandered around the country (Zhan, 2016, p. 70). In autumn, he returned to Jinling (alternative name of Nanjing) from the Kueichi (会稽), Chekiang Province (浙江省), and wrote the poem Song of Jinling (III) (《金陵三首・其三》):

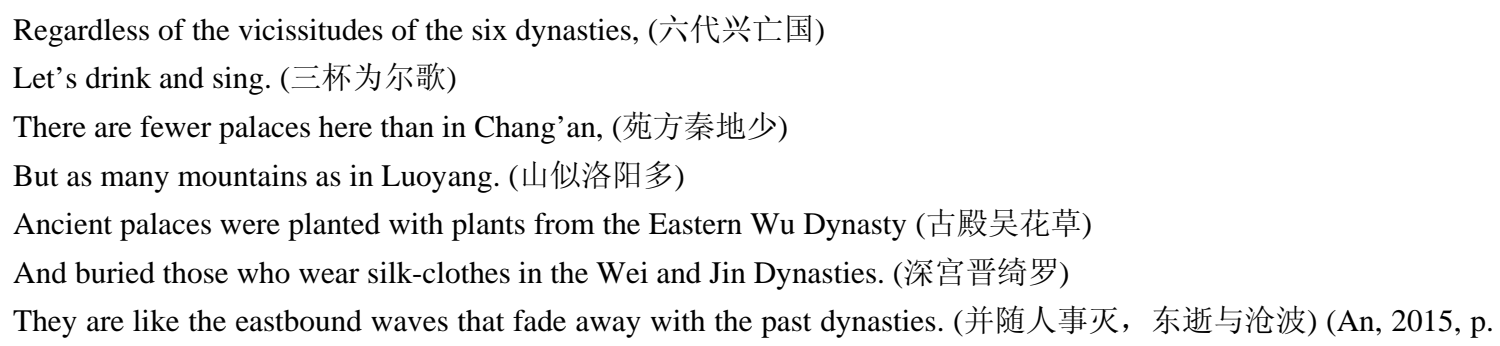

An Qi believes that Li Bai's poem is a satire of the past and the present. Because he himself was deported from the court and the government was getting worse and worse, he expressed his deep feelings about the rise and fall of the dynasty. He compared Jinling with Chang'an and Luoyang, which made the three cities bleak. It is said that "the scenery is not very different, but the dynasty's momentum is no longer the same as before" (An, 2015, p. 744).

In the ninth year of Tianbao (750 A.D.), Li Bai began to wait calmly for opportunities after he was driven out of imperial court. In May, he traveled from Jinling to Lushan Mountain (庐山). On his way through Dangtu County (当涂县), Li Bai wrote a poem Farewell to Cousin Li Ji, the Military Officer in Liyang, on Lingxiao Terrace of the Huangshan Mountain (《登黄山凌歊台送族弟溧阳尉济充泛舟赴华阴》):

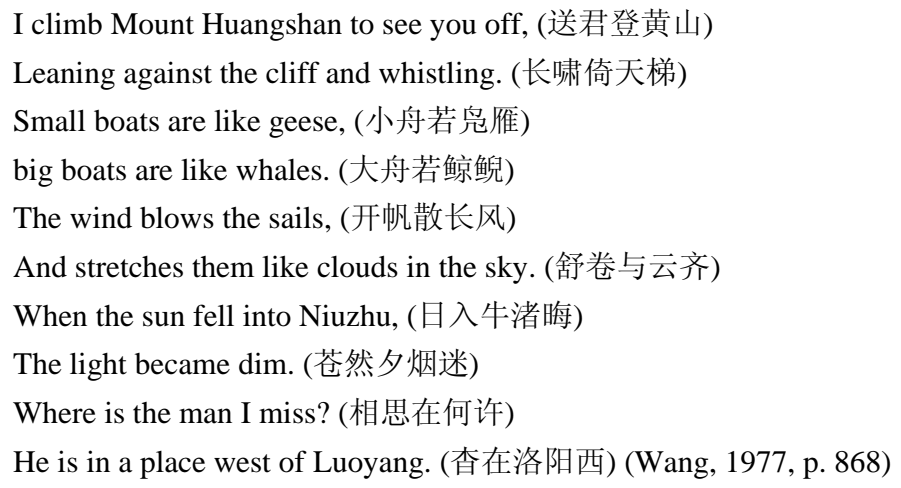

At that time, Li Ji, Li Bai’s cousin, was going to Huayin (华阴) to carry grain. Li Bai went to Huangshan to say farewell to Li Ji. He watched the sail take advantage of the wind, and thought that one's fortune is just 
like this, needed good opportunity. At this time, Li Bai was still very eager to be reused, but he did not say obviously. While missing his brother, he also expressed his longing for Chang' an, because Li Ji is going to Huayin, where not far from Chang'an in the west of Luoyang. He wrote "Luoyang" literally, but missed “Chang'an” in his heart.

In the spring of the 10th year of Tianbao (751 A.D.), Li Bai still lived in Eastern Lu (An, 2015, p. 896); he wrote To Yuan Canjun (a Military Staff Officer)—Recalling the Time We Spent Together in the Past (《忆旧游 寄谯郡元参军》). The first two rhymes of this poem:

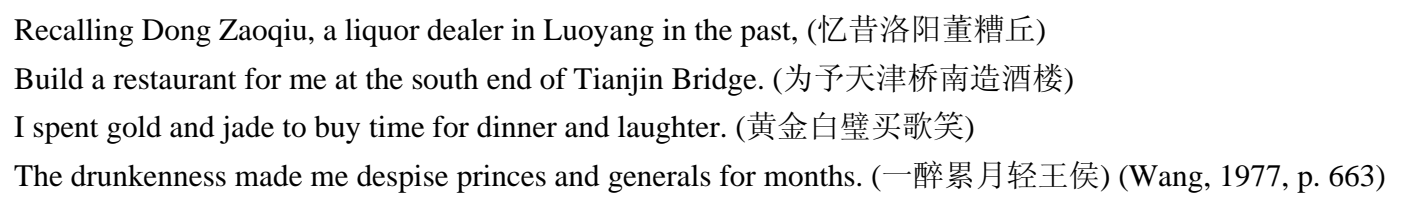

The title of the poem directly points out "Recalling the Past" and writes four trips of Li Bai and Yuan Yan. The first time was when he came out of Chang' an in the 19th year of Kaiyuan (731 A.D.), he played, gathered, and drank with his friends in Luoyang. This is different from the comfortable atmosphere in which Li Bai wrote "Driving across Tianjin Bridge" before. Here is a reminiscence of the past prosperous times. The subjective feelings of "Luoyang" are more than ever before, which fully show the sentiment that good times and beautiful scenery are easy to pass away.

In the 11th year of Tianbao Era (752 A.D.), Li Bai left the Eastern Lu and entered Hebei (An, 2015, p. 927). He wrote Say Goodbye to Su Yin, the County Decree in Wei (《魏郡别苏明府因北游》), “Like Su Qin from Luoyang, you are both rich in vocabulary and articulate” (Wang, 1977, p. 715). He compared his friend Su Yin with Su Qin to highlight his friend's literary demeanor and free-spirited personality. In the same year, Li Bai also wrote Writing Love in Lieu of a Lady (《代赠远》). The whole poem revolves around the line "Send out my lovesickness; fear that the monarch does not see it". The narrative is calm and eloquent. On the surface, it seems that the narrative style is not disturbing. In fact, at the beginning of the poem, "I am from Luoyang, my husband is from You Zhou” (妾本洛阳人, 狂夫幽燕客) (Wang, 1977, p. 1176), has laid something foreshadow. The poem points out that this woman is a fair maiden who grew up in the capital city, so when she was abandoned by her husband, it is even more touching and regrettable. During this period, "Luoyang" in Li Bai's poems highlighted "outstanding people" and slightly broke away from the nostalgia for the past prosperity of the capital city, with a sense of spiritual renewal.

In the first year of Zhide Era (756 A.D.), that is, the 15th year of Tianbao, the year's reign title has been changed in July. Li Bai wrote Proceed Northward (《北上行》), “Whales are abundant in the Yellow River, monsters are stationed in Luoyang” (奔鲸夹黄河, 丵齿屯洛阳). Yang Qixian commented: “This poem was written by Li Bai when An Lushan rebelled. Monsters refer to the rebels, and whales refer to Shi Siming, Cui Qianyou and others”. Wang Qi commented: “This poem means that An Lushan occupies Luoyang to seize power”. They all thought the nature of the poem is realism. Other interpreters, such as Fan Xiwen, Xiao Shiyun, and Hu Zhenheng (胡震亨), all said that Li Bai’s poem was “just an ancient Yuefu poem journey of hardship and cold, adjusted the language slightly". However, they all agreed that it "wrote the An-Shi Rebellion by writing beasts stationed in Luoyang”, “like the national style in the Book of Songs (《诗经•国风》) (An, 2015, p. 927), full of loyalty, patriotism and war aversion”. 
From a comprehensive perspective, "Luoyang” metaphorically refers to "the fall of the regime". After that, Li Bai wrote poem On the Way to Escape (IV) (《奔亡道中五首・其四》):

Hangu Pass became Jade Gate Pass. (函谷如玉关)

When on earth can we come without mishap? (几时可生还)

Luoshui River became Yishui River, (洛川为易水)

And Songshan Mountain became Yanshan Mountain. (嵩岳是燕山) (Wang, 1977, p. 1016)

Wang Qi's commentary is: "Luoshui River and Songshan areas have become borders, and local customs have changed because of the invasion of soldiers from alien races”. An Qi said,

This poem was written when Li Bai and his wife Zong’s on their way from the Song City (宋城) to the south. In the two sentences, four place names were used to describe how critical the situation of the country was when the interior of the Central Plains suddenly became a border. (An, 2015, p. 1205)

At this time, the regional concept of "Luoyang" extended to the whole Central Plains, and there were more layers of dynamic meaning besides the static reference. The momentum of language and the sense of pictures were enhanced, showing the poet's real psychological state of fear, anxiety, and indignation during his escape.

In the second year of Zhide (757 A.D.), Li Bai was implicated because he followed Li Lin (Prince of Yong, the 16th Son of Li Longji, Emperor Xuanzong of Tang Dynasty) and eventually exiled. In this year, there were many reviews and judgments about the An-Shi Rebellion and his painful political experience. He began to use such expressions as "Luoyang" and "Luoyang Chuan" steadily. For instance, the poem Reflections on the Process of Fleeing Southward (《南奔书怀》):

The comet named Chan Qiang is flying over He-Luo region, (换抢扫河洛)

Looks like dividing the world in two with a ravine. (直割鸿沟半)

The fortune destiny is not yet completely on the wane. (历数方未迁)

However, like clouds and thunders meet, many catastrophes are brewing. (云雷屡多难) (Wang, 1977, p. 1141)

Chan Qiang (换抢) is the name of a comet. The ancients believed that its appearance meant the advent of military disasters. Li Bai used it as a metaphor for the army of An Lushan, which swept the Central Plains. In the poem, the astronomical terms "Chan Qiang” is used to match the geographical term "He-Luo", and then "fortune destiny", "clouds and thunders" are used to coincide with the meaning of "clouds accumulate into rain, thunder shocks will stir up the four sides”, which selected from Zhun Diagram (屯卦) of The Book of Changes (《周易》). It indirectly points out that the dynasty did not perish but sufferings continued, and the root of disaster has already formed. Another poem Send the Scholar Zhang to the Army (《送张秀才从军》):

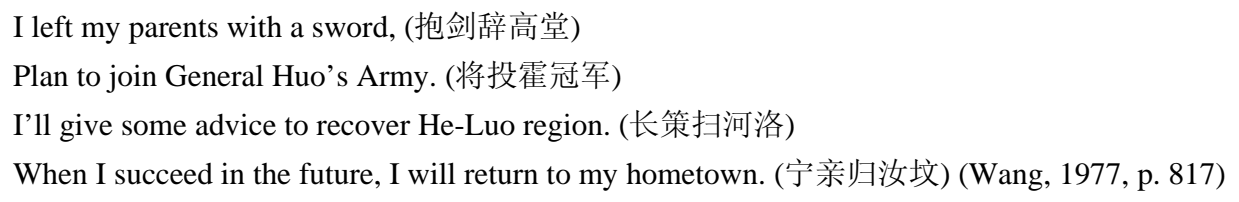

Zhang Mengxiong, a scholar, who will join Cui Huan's army. The poet hopes that he can offer some strategies to help the Imperial Army sweep the An-Shi Rebels in He-Luo area. Only in this way can he return to his native villages. Here is the word "Ru Fen” (汝坟) used to match "He-Luo". "Ru Fen” is the embankment on Rushui River. Li Bai used it to refer to the places where Rushui flows, including Baofeng (宝丰), Xiangcheng 
(襄城), Yancheng (㔭城), Shangcai (上蔡), Runan (汝南), and so on, which were occupied by An Lushan at that time.

The latter poem is different from the former in terms of diction. It uses two geographic nouns with overlapping references to match each other. Then, whether the rebels sweep He-Luo or the Imperial Army sweep the rebels away, Li Bai can use "sweep He-Luo region” to integrate historical facts into geography, so that some special words can bear the brand of war.

According to this clue, further explore the use of "Luoyang Chuan” by Li Bai. The poem To Your Colleagues at the Navy’s Banquet ( 《在水军宴赠幕府诸侍御》) begins with four rhymes:

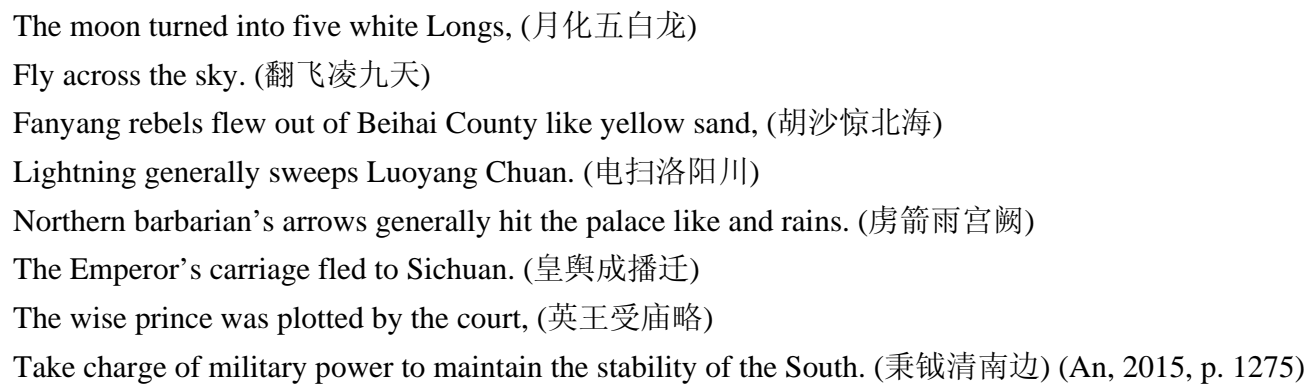

In the first month of the second year of Zhide (757 A.D.), Li Bai wrote this poem in the navy of Prince of Yong, earlier than the other two poems, Reflections on the Process of Fleeing Southward and Send the Scholar Zhang to the Army. The poem describes the capture of Luoyang by An Lushan. Firstly, the first three rhymes make clear the outline of the matter, starting with the dream of Liang Yannian (an official who holds astronom and calendar) that "The moon turned into five white Longs". This story is recorded in the Sixteen Feudal Countries Chunqiu (《十六国春秋). Secondly, “Fanyang (范阳) rebels flew out of Beihai County (北海) like yellow sand" and "Lightning generally sweeps Luoyang Chuan " are taken as a pair of substantive antithesis.

Analyzing the linguistic structure of the above sentences, the implied "subject" in "sentences without subject” is the rebel army headed by An Lushan. "Lightning generally sweeps Luoyang Chuan” describes the rebels marching all the way from "Hebei Dao" to "Henan Dao". The rebel forces have gained momentum and invaded a vast area, which is extremely shocking.

In the poem, "The Emperor's carriage fled to Sichuan" is the direct consequence of "Lightning generally sweeps Luoyang Chuan”. This is Li Bai's judgment of the current situation and even the decline of the national situation. In his view, the occupation of Luoyang Chuan has marked that the "power center" has been severely impacted, and it is not necessary to wait for the breakdown of Chang'an.

Tracing back to the above, Emperor Yang of the Sui Dynasty has opened up the route and feasibility of moving the capital eastward since he built the East Capital. With the transfer and accumulation of wealth, the transfer of power has a considerable basis, and the deliberate distinction between the names and status of the two capitals has become meaningless. Since Wu Zetian established Luoyang for the capital, the essential pattern of the co-existence of "two capital" has been determined. To some extent, both can be used as regional symbols of imperial power. Then, whether Li Bai spoke of "Chang'an” in his poems Lotus Flower Peak in Huashan Mountain, cannot be used as a criterion to determine the time and place of his creation. The annotators of the past dynasties focused on this, but did not thoroughly sort out the relationship between them. Naturally, they formed the attitude of polarizing "poem about immortals" or "poem realistic" in their interpretation. 
On the Basis of previous discrimination, restudy these poem lines, "Looking down at Luoyang Chuan, I see the rebels of An-shi suddenly. Bleeding everywhere, all beings are abused by jackals and wolves cruelly". These sentences are very similar to the four rhymes of another poem To Your Colleagues at the Navy's Banquet, both in expressive techniques and in content. They are Li Bai's retrospect and judgment on the capture of Luoyang by An Lushan and the escape of the emperor. "Looking down at Luoyang Chuan, I see the rebels of An-Shi suddenly" is another expression of "Lightning generally sweeps Luoyang Chuan”, "Lightning generally sweeps Luoyang Chuan, The comet named Chan Qiang is flying over He-Luo region”, sharing the same subject, that is, the An-Shi Rebels. Xiao Shiyun believed that when An-Shi rebelled, the court recovered the two capitals with the help of Huihe soldiers. Compared with the above, his view is wrong. It is not credible to annotate the specific writing period of Li Bai's poems with this kind of viewpoint.

In the series of works related to "He-Luo" and "Luoyang Chuan" written by the second year of Zhide Era, Li Bai never mentioned anything about recovering the two capital cities. Because Li Chu, Prince of Guangping (广平王李俶), and Guo Ziyi (郭子仪) led Shuofang (朔方), Anxi (安西), and Huihe (回纥) soldiers to recover Chang'an in September of this year, and only after An Qingxu fled to Hebei in October did they recover Luoyang. Li Bai fled to Pengze in February after Li Lin, Prince of Yong’s defeat. Then, it can be inferred that the period of his poetry writing can be precisely between January, the first year of Zhide to October of the second year of Zhide. No matter how Li Bai adjusted his route, he should not have entered Tongguan (潼关), Shaanxi Province, nor can he be situated on Huashan Mountain in the west of Luoyang and northeast of Chang'an, let alone Xiao Shiyunn said that "Li Bai was just in Huashan Yuntai Taoist Temple, the whole poem seems to be a documentary work".

What is worth exploring is that after the second year of Zhide, Li Bai never used "Luoyang Chuan" (the special reference to "Luoyang Plain") again and returned to "Luoyang City", "the gifted scholars of Luoyang". For instance, "When can the emperor call in the gifted scholars of Luoyang again and ask him about the plan of governing the country”, is chosen from the poem Pardoned in Exile (《放后遇恩不沾》) (An, 2015, p. 1383). "The gifted scholars of Luoyang, is banished to Xiangjiang Erea, sail with another talent Li Yuanli. These two immortals are at ease under the moon”, is chosen from the poem On Lake Dongting (III) (《陪族叔刑部侍郎晔 及中书贾舍人至游洞庭五首・其三》) (An, 2015, p. 1427).

The meaning of "Luoyang” in Li Bai's poems ranges from pure "geographical nouns" to places where people can seek their merits, and then lament "the decline of state power" and finally return to "calm and peaceful". It overlaps with the course of his life, without hindrance. And "Luoyang Chuan" has undoubtedly been integrated into the allusion of "An-Shi Rebellion", which has distinct individual "cut-off value".

As for why Li Bai did not use "Luoyang Chuan" in the future, the author borrowed the theory of archaeology to say that "compared with gold and silver vessels, ceramics vessels are more meaningful in dating, because the latter is fragile". This "Luoyang Chuan", which appeared only four times in classical poetry, is not as stable and lasting as "Luoyang", but in Li Bai's poems, it shows us the poet's situation, cognition, and inner world in the most difficult period of the An-Shi Rebellion.

\section{Conclusion}

In the poem Lotus Flower Peak in Huashan Mountain, Li Bai fuses the dream with soul because of mountaineering and fairyland traveling, then returns to his soul because he sees the breaking of the lower boundary in the clouds-rising gently and falling heavily. The structure of the poem is not complicated. As far 
as the content is concerned, it can be divided into two parts: The first five rhymes and the last two rhymes, respectively, express the romantic fairy illusion and the miserable encounters in reality. In contrast, the collapse of the real world becomes more frightening and nightmare-like. The poet's state of mind, which is unable to escape because of his patriotism, is also expressed in his poems, which makes people read and sigh again and again after a thousand years. In summary, this high artistic attainment is mainly manifested in the following points:

Firstly, the poem line "Lotus Flower Peak in Huashan Mountain" does not use the name "Huashan" directly, but first uses its name "Lotus Flower" to arouse association and naturally transit to a true Lotus, which is held by that Yunü named Star, and then guided by her to meet the immortal Wei Shuqing, so as to travel among the clouds together. The above links are extremely connected. Li Bai writes imaginary things in a real and agile way, skillfully integrates "plot" into the form of poems and prose which emphasizes "aggregation" of content, makes the whole poem dynamic and quiet, and creates artistic effects that are dreamlike but like experiencing them personally.

Secondly, the poet is very careful about the use of geographical nouns. Even if he writes fictional situations, he will have a precise grasp of their category, location, and reference. For example, "Climbing Yuntai Peak together", which is the sentence in a Pre-Tang style poem, there is no need to use even-tone words for rhyming. The reason why the poet chose "Yuntai Peak" is that it is located in the north of the Huashan Montain, most suitable for people look down on the east and west. Li Bai’s fictional immortal route is to travel eastward, which is just contrary to the rebels' line of marching. If he stops at Yuntai Peak, he can see the whole situation from the top of the cloud. This kind of fictitious and realistic technique makes the perfect integration of "immortal illusion" and "current situation". Even if it turns abruptly, it is also in reason. As for the use of "Luoyang Chuan", the poet's special life experience and mental journey of the region are integrated, and his deep concern for the current situation and the country is accurately conveyed to the readers.

Thirdly, the whole poem highly integrates romance and realism. It is neither a traditional poem about immortals nor a typical political satire poem. The first five rhymes are ethereal and vague, which not only makes the cruelty of reality clear, but also weakens the cruelty contained in them ingeniously. The last two rhymes change the perspective and change the subject realism, which endows the poem about immortals with special "ending” and "meaning”, makes the emotions in the poems heavy and full, and deepens the theme.

In a comprehensive view, Li Bai does not like the specific narrative writing techniques with large space, but tends to choose special words, romantic style, and effective structure, highly refine historical facts, and process them with imagery. This feature is not uncommon in Li Bai's poems, but has not been fully valued by later commentators. It requires researchers to re-examine the distinction and controversy of "style" in the past, the mentality of judgment, and the way of research, become flexible in interpreting poetry, gradually get rid of the vague way of ancient annotation, so as to construct the annotation and interpretation system of ancient Chinese literature in the contemporary era.

\section{References}

An, Q. (2015). The chronicling in annotations to annals of complete works of Li Bai. Beijing: Zhong Hua Book Company.

Chen, Y. D. (1994). Textual research of collections of Tang Dynasty: Corpus of Su Ting. Journal of Zhejiang Normal University, 1, 16-19.

College of Liberal Arts of Inner Mongolia University. (2001). Selection of 50 Years (IV). Hohhot: Inner Mongolian University Press. 
Editorial Department of Zhonghua Book Company. (1999). The complete collection of Tang poems: Revised and enlarged edition (Vol. LXXIV). Beijing: Zhong Hua Book Company.

Li, F. (1960). Imperial readings of the Taiping Era. Beijing: Zhong Hua Book Company.

Liang, Q. Z. (2015). Centralized annotation of yellow court classic. Beijing: Central Compilation \& Translation Press.

Ouyang, X., \& Song, Q. (1975). The new history of the Tang Dynasty. Beijing: Zhong Hua Book Company.

$\mathrm{Pu}$, J. Z. (2013). Ancient poems arranged according to seasons. Xi'an: Sanqin Publishing House.

Qu, T. Y., \& Zhu, J. C. (1980). Annotations of Li Bai's collections of poems. Shanghai: Shanghai Chinese Classics Publishing House.

Tan, Q. X. (1996). The historical atlas of China. Beijing: Sino-Maps Press.

Wang, Q. (1977). The complete works of Li Taibai. Beijing: Zhong Hua Book Company.

Wei, S., \& Du, B. (2006). A new account of the two capitals \& miscellanies of Daye Era of Sui Dynasty. Xi'an: Sanqin Publishing House.

Work Councils of Si Ku Quan Shu. (2005). Si Ku Quan Shu in Wenjin Chamber (Vol. CLIX). Beijing: The Commercial Press.

Xu, Y. C. (2014). Selected poems of Li Bai. Beijing: China Translation \& Publishing House.

Yang, Q. X., \& Xiao, S. Y. (2006). Li Taibai’s poems with supplementary annotations by classification. Classical Seminar Series. Tokyo: Jigu Academy.

Zhan, Y. (2016). Annals of Li Bai's poetic and prose works. The complete works of Zhan Ying (Vol. V). Shijiazhuang: Hebei Education Press.

Zhou, Z. H. (2013). Sixteen lectures on Chinese historical political geography. Beijing: Zhong Hua Book Company. 